\title{
SPATIAL VARIABILITY OF AGGREGATE STABILITY IN LATOSOLS UNDER SUGARCANE ${ }^{(1)}$
}

\author{
Zigomar Menezes de Souza ${ }^{(2)}$, José Marques Júnior ${ }^{(3)}$, Gener Tadeu \\ Pereira $^{(4)}$ \& Carolina Maria Sánchez Sáenz ${ }^{(5)}$
}

\begin{abstract}
SUMMARY
The spatial variability of soils under a same management system is differentiated, as expressed in the properties. The spatial variability of aggregate stability of a eutrophic Red Latosol (ERL) and a dystrophic Red Latosol (DRL) under sugarcane was characterized. Samples were collected in a regular $10 \mathrm{~m}$ grid, in the layers $0.0-0.2$ and $0.2-0.4 \mathrm{~m}$, with 100 points per area, and the following properties were determined: geometric mean diameter (GMD) of aggregates, mean weight diameter (MWD) of aggregates, percent of aggregates in the $>2.0 \mathrm{~mm}$ class and organic matter (OM) content. The eutrophic Red Latosol (ERL) had a higher aggregate stability thn the dystrophic Red Latosol (DRL), which may be attributed to the higher clay and OM content and the gibbsitic mineralogy of this soil class. The differentiated evolution of the studied Oxisols explains the wider range and lower variation coefficient and variability, for all properties studied in the eutrophic
\end{abstract} Red Latosol.

Index terms: spatial distribution, physical properties, organic matter, Saccharum officinarum.

\section{RESUMO: VARIABILIDADE ESPACIAL DA ESTABILIDADE DE AGREGADOS EM LATOSSOLOS SOB CULTIVO DE CANA-DE-AÇÚCAR}

Solos submetidos ao mesmo sistema de manejo manifestam variabilidade espacial diferenciada de seus atributos. A variabilidade espacial da estabilidade de agregados foi

\footnotetext{
(1) Part of Doctoral Thesis of the first author, financed by FAPESP. Recebido para publicação em junho de 2007 e aprovado em fevereiro de 2009.

(2) Professor Doctor, Water and Soil Department, Agricultural Engineering School - UNICAMP. Cidade Universitária Zeferino Vaz s/n, Caixa Postal 6011, CEP 13083-875 Campinas (SP). E-mail: zigomarms@agr.unicamp.br

(3) Professor Doctor, Soils and Fertilizers Department, FCAV/UNESP, Jaboticabal (SP). E-mail: marques@fcav.unesp.br

(4) Professor Doctor, Exact Sciences Department, FCAV/UNESP, Jaboticabal (SP). E-mail: genertp@fcav.unesp.br

(5) Master's student, Water and Soil Department, FEAGRI/UNICAMP, Campinas (SP). E-mail: aniloraczneas@gmail.com
} 


\begin{abstract}
caracterizada em um Latossolo Vermelho distrófico e Latossolo Vermelho eutroférrico, sob cultivo de cana-de-açúcar. Foram realizadas amostragens de terra nos pontos de interseção de uma malha de $10 \times 10$ linhas, espaçadas de $10 \mathrm{~m}$, totalizando 100 pontos de amostragem por área, coletadas nas camadas de 0,0-0,2 e 0,2-0,4 $\mathrm{m}$ de profundidade, para determinação de diâmetro médio geométrico (DMG), diâmetro médio ponderado (DMP), agregados na classe $>2,0 \mathrm{~mm}$ e teor de matéria orgânica do solo. O Latossolo Vermelho eutroférrico apresenta maior estabilidade de agregados quando comparado com o Latossolo Vermelho distrófico, condizente com o maior teor de argila, matéria orgânica e mineralogia gibbsítica. A evolução diferenciada dos Latossolos estudados explica os maiores alcances, o menor coeficiente de variação (CV) e a menor variabilidade, observados no Latossolo Vermelho eutroférrico para todos os atributos estudados.
\end{abstract}

Termos de indexação: distribuição espacial, atributos físicos, teor de matéria orgânica, Saccharum officinarum.

\section{INTRODUCTION}

Soil aggregates are formed and stabilized by means of physical, chemical and biological processes, which can vary from one location to another within a landscape. These processes are determined by substances that influence aggregation and aggregate stabilization, particularly the persistent cementing agents, e.g., clay, colloidal silica, organic compounds, polyvalent cations, calcium carbonate, Fe oxide, and hydroxide and Al (Silva \& Mielniczuk, 1997).

The intensive soil use and the systematic machine application under inadequate soil humidity conditions in sugarcane, with predominance of excessive artificial preparation and burning of crop residues significantly modify the original physical properties (Souza et al., 2005). Main modifications are observed in the decrease of proportions of organic matter and the structure degradation evidenced by the increased soil density, soil microporosity and penetration resistance, as well as the decrease of aggregate size, macroporosity and permeability.

Changes in soil structure and the rupture of aggregates resulting from an improper agricultural use usually cause restrictions to root growth, reducing water and nutrient use of crops. Soil structures can be evaluated indirectly, as for example by the determination of the stable aggregate quantity in water (Corrêa, 2002). Methods that quantify and qualify structure conditions are important to assess the soil quality (Carpenedo \& Mielniczuk, 1990). Souza et al. (2005) studied the effect of the sugarcane harvesting system and fodder handling, and verified that in the cane burning system, soil property degradation is evidenced by the decrease of aggregate stability. Therefore, knowledge on aggregate stability is important when defining soil quality indicators (Sá et al., 2000).

When a soil attribute varies from one place to another with OMe grade of continuity, geostatistics allows a spatial view, based on the spatial dependence, which is useful for planning and information control expressed by spatial dependence. The geospatial modeling allows a quantitative description of the spatial variability of soil properties and an unbiased prediction with minimal variance of the values of such properties, at unsampled sites. Using this variability makes geostatistics an effective tool to support decisions of soil, water and crop management. Interventions to correct undesirable variations in nutrient and water supply and even management, can be determined based on isovalue maps of variables of interest (Vieira, 2000). The purpose of this paper was therefore to characterize the spatial variability of aggregate stability in a dystrophic Red Latosol and eutrophic Red Latosol under sugarcane.

\section{MATERIAL AND METHODS}

The study areas are located in the Northeast of the State of São Paulo, in the cities Guariba (SP) and Jaboticabal (SP) (lat $21^{\circ} 19^{\prime} \mathrm{S}$ and long $48^{\circ} 13^{\prime} \mathrm{W}$, at a mean of $600 \mathrm{~m}$ asl). The terrain is slightly hilly and declivity in the mean from 3 to $8 \%$. The regional climate classification according to Köppen, is mesothermal with dry winter (Cwa), with a mean annual rainfall of $1,400 \mathrm{~mm}$, concentrated between November and February. The natural vegetation consisted of semideciduous tropical forest and riparian vegetation.

The soils in the areas were classified according to Embrapa (1999) as kaolinitic clay texture dystrophic Red Latosol (DRL), developed from sandstones of the Bauru Group, Adamantina Formation. The gibbsitic, very clayey texture eutrophic Red Latosol (ERL) had developed on the basalts of the São Bento Group, Serra Geral Formation (Figure 1). This litostratigraphic formation is found in large areas in Northeastern São Paulo. The experimental areas had been used for sugar cane production for more than 30 years, using semimechanical conventional planting, mechanical tilling, together with the application of herbicides and fertilizers. On both areas sugar cane had been replanted five times. 
AREA 1 - DYSTROPHIC RED LATOSOL (DRL)

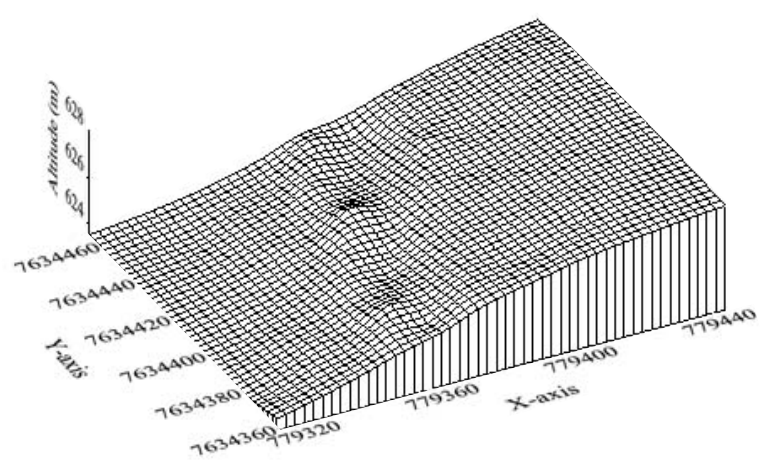

AREA 2 - EUTROPHIC RED LATOSOL(ERL)

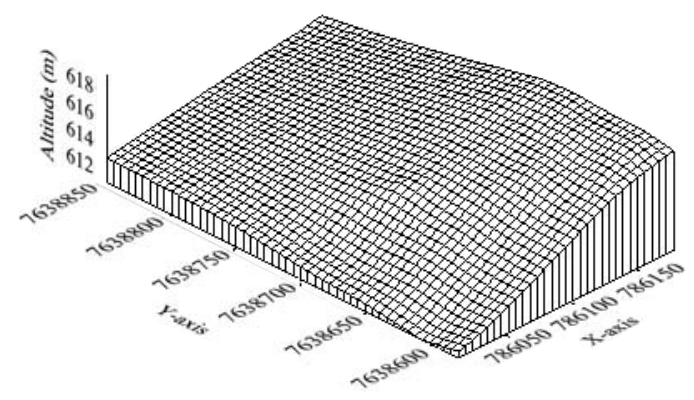

Figure 1. Altitude variation maps in $x$ and $y$ directions of the study areas.

The soils were sampled at the intersection points of a geo-referenced, regular $10 \mathrm{~m} \times 10 \mathrm{~m}$ grid, in the layers $0.0-0.2$ and $0.2-0.4 \mathrm{~m}$. Each $100 \times 100 \mathrm{~m}$ area (1 ha) contained 100 points. At every point, a $0.3 \times 0.3 \mathrm{~m}$ trench was opened to a depth of $0.6 \mathrm{~m}$, to determine the geometric mean diameter (GMD) properties, and mean weight diameter (MWD) of the aggregates, aggregates in the $>2.0 \mathrm{~mm}$ class and soil organic matter (OM) content.

The earth samples were slightly harrowed by hand and passed through a $9.51 \mathrm{~mm}$ sieve and air-dried, for analyses related to aggregation. Part of the samples were passed through a $2.0 \mathrm{~mm}$ sieve (air-dried fine earth), to determine the OM content. Aggregate separation and stability were determined in different diameter classes $(>2.0 ; 2.0-1.0 ; 1.0-0.25 ; 0.25-0.10$; $0.10-0.05$ and $<0.05 \mathrm{~mm}$ ), as described by Kemper \& Chepil (1965), with modifications. After the aggregates had been in contact with water on the $4.76 \mathrm{~mm}$ sieve for $15 \mathrm{~min}$, the material mass retained in each sieve was oven-dried at $105^{\circ} \mathrm{C}$. The geometric mean diameter (GMD), mean weight diameter (MWD) and aggregate percentage in the class $>2.0 \mathrm{~mm}$ were calculated. The organic matter content was determined according to the method described by Embrapa (1997).

The soil physical properties were analyzed by descriptive statistical analysis, calculating the mean, median, variation coefficient, asymmetry coefficient and Kurtosis coefficient. The hypothesis of data normality was verified by the Kolmogorov-Smirnov test, using the software SAS (Schlotzhaver \& Littell, 1997).

The spatial dependence was analyzed by means of adjustments of semi-variograms (Vieira, 2000), based on the presupposition of stability of the intrinsic hypothesis, which is determined by:

$$
\hat{\gamma}(h)=\frac{1}{2 N(h)} \sum_{i=1}^{N(h)}\left[Z\left(x_{i}\right)-Z\left(x_{i}+h\right)\right]^{2}
$$

where $N(h)$ is the number of experimental pairs of observations $\mathrm{Z}\left(\mathrm{x}_{\mathrm{i}}\right)$ and $\mathrm{Z}\left(\mathrm{x}_{\mathrm{i}}+\mathrm{h}\right)$, separated by distance $\mathrm{h}$. The semi-variogram is represented by the graph $\hat{\gamma}(h)$ versus $h$. By the fitting of a mathematical model to the calculated values of $\hat{\gamma}(h)$, the coefficients of the theoretical model are estimated for the semivariogram $\left(\mathrm{C}_{0}\right.$ - nugget effect; $\mathrm{C}_{0}+\mathrm{C}_{1}$ - sill; and a range). To analyze the grade of spatial dependence of the study properties, the classification of Cambardella et al. (1994) was used, in which the semi-variograms with a nugget effect of $<25 \%$ are considered to have strong spatial dependence, between 25 and $75 \%$ is moderate and $>75 \%$ of the sill value is considered weak.

The spherical, exponential, linear and Gaussian semi-variogram models were considered and were adjusted using the program $\mathrm{GS}^{+}$(Robertson, 1998). These models were also used in the development of isoline maps (krigage). In case of doubts among more than one model for the same semi-variogram, the higher coefficient value of correlation was considered, obtained by the cross validation method. The Surfer program was used (Golden Software, 1999) to draw spatial distribution maps of variables The maps created by Surfer were exported to the Idrisi Kilimanjaro program (Eastman, 1999), where the area of each attribute class was calculated in relation to the total area.

\section{RESULTS AND DISCUSSION}

The Kolmogorov-Smirnov test indicated normality for GMD in ERL and DRL and MWD in DRL in the studied layers (Table 1). However, the mean and median values are close for all variables, with symmetrical distributions. According to Little \& Hills (1978), when the mean, median and mode values are similar, the data have a regular or nearly regular distribution. This could mean that the central tendency measures are not subject to outliers in the distribution (Cambardella et al., 1994), indicating that all properties studied are approaching a regular distribution and that the data are adequate for the use for geostatistics, so no transformation is required to establish data regularity.

According to Webster (2001), an asymmetry value of up to 0.5 indicates a regular distribution of a 
Table 1. Descriptive statistics for the variables geometric mean diameter, mean weight diameter, aggregates in class $>2.0 \mathrm{~mm}$ and organic matter proportion, in an eutrophic Red Latosol and a dystrophic Red Latosol in layers of 0.0-0.2 and 0.2-0.4 m

\begin{tabular}{|c|c|c|c|c|c|c|c|}
\hline \multirow{2}{*}{ Variables } & \multirow{2}{*}{ Layer } & \multicolumn{6}{|c|}{ Statistics } \\
\hline & & Mean & Median & CV & Asym metry & Kurtosis & $d^{(5)}$ \\
\hline & \multicolumn{7}{|l|}{$\mathrm{m}$} \\
\hline & \multicolumn{7}{|c|}{ dystrophic Red Latosol } \\
\hline \multirow{2}{*}{$\operatorname{GMD}(\mathrm{mm})^{(1)}$} & $0.0-0.2$ & 1.56 & 1.53 & 37.90 & 0.21 & -0.96 & $0.07^{\mathrm{ns}}$ \\
\hline & $0.2-0.4$ & 1.57 & 1.54 & 36.61 & 0.33 & -0.49 & $0.06^{\mathrm{ns}}$ \\
\hline \multirow{2}{*}{ WMD $(\mathrm{mm})^{(2)}$} & $0.0-0.2$ & 2.86 & 2.88 & 29.23 & 0.15 & -0.62 & $0.07 \mathrm{~ns}$ \\
\hline & $0.2-0.4$ & 2.88 & 2.84 & 26.01 & 0.22 & 0.14 & $0.05^{\mathrm{ns}}$ \\
\hline \multirow{2}{*}{$>2.0 \mathrm{~mm}(\%)^{(3)}$} & $0.0-0.2$ & 36.42 & 36.24 & 43.16 & 0.28 & -0.80 & 0.09 \\
\hline & $0.2-0.4$ & 35.84 & 35.42 & 36.15 & 0.44 & 0.01 & 0.08 \\
\hline \multirow{2}{*}{$\mathrm{OM}\left(\mathrm{g} \mathrm{dm}^{-3}\right)^{(4)}$} & $0.0-0.2$ & 16.08 & 16.02 & 14.05 & 0.25 & -0.31 & 0.15 \\
\hline & $0.2-0.4$ & 14.03 & 14.01 & 19.89 & 0.02 & -0.45 & 0.12 \\
\hline \multirow{2}{*}{ Clay $\left(\mathrm{g} \mathrm{kg}^{-1}\right)$} & $0.0-0.2$ & 354 & 356 & 6.99 & -0.09 & -0.25 & 0.10 \\
\hline & $0.2-0.4$ & 368 & 370 & 6.80 & -0.01 & -0.23 & 0.13 \\
\hline \multirow{2}{*}{ Silt $\left(\mathrm{g} \mathrm{kg}^{-1}\right)$} & $0.0-0.2$ & 68 & 70 & 21.99 & 0.43 & 0.34 & 0.18 \\
\hline & $0.2-0.4$ & 64 & 80 & 21.90 & 0.25 & -0.24 & 0.16 \\
\hline \multirow{3}{*}{ Sand $\left(\mathrm{g} \mathrm{kg}^{-1}\right)$} & $0.0-0.2$ & 578 & 580 & 16.71 & -0.07 & 0.06 & 0.09 \\
\hline & $0.2-0.4$ & 568 & 572 & 17.72 & -0.19 & -0.06 & 0.13 \\
\hline & \multicolumn{7}{|c|}{ eutrophic Red Latosol } \\
\hline \multirow{2}{*}{ GMD (mm) } & $0.0-0.2$ & 2.24 & 2.30 & 33.40 & -0.09 & -0.68 & $0.07 \mathrm{~ns}$ \\
\hline & $0.2-0.4$ & 2.28 & 2.30 & 34.45 & 0.01 & -0.16 & $0.05^{\mathrm{ns}}$ \\
\hline \multirow{2}{*}{ WMD (mm) } & $0.0-0.2$ & 3.77 & 3.85 & 27.31 & -0.47 & -0.94 & 0.10 \\
\hline & $0.2-0.4$ & 3.83 & 3.98 & 26.01 & -0.30 & -0.90 & 0.11 \\
\hline \multirow{2}{*}{$>2.0 \mathrm{~mm} \mathrm{( \% )}$} & $0.0-0.2$ & 60.21 & 59.22 & 28.45 & 0.20 & -1.34 & 0.11 \\
\hline & $0.2-0.4$ & 55.94 & 56.97 & 26.05 & -0.29 & -0.43 & 0.14 \\
\hline \multirow{2}{*}{$\mathrm{OM}\left(\mathrm{g} \mathrm{dm}^{-3}\right)$} & $0.0-0.2$ & 27.01 & 27.50 & 13.37 & -0.27 & -0.19 & 0.13 \\
\hline & $0.2-0.4$ & 23.07 & 23.00 & 16.02 & -0.12 & -0.86 & 0.13 \\
\hline \multirow{2}{*}{ Clay $\left(\mathrm{g} \mathrm{kg}^{-1}\right)$} & $0.0-0.2$ & 622 & 620 & 2.91 & -0.04 & -0.75 & 0.12 \\
\hline & $0.2-0.4$ & 637 & 636 & 3.97 & 0.10 & -0.87 & 0.15 \\
\hline \multirow{2}{*}{ Silt $\left(\mathrm{g} \mathrm{kg}^{-1}\right)$} & $0.0-0.2$ & 210 & 208 & 13.15 & -0.13 & -0.79 & $0.07^{\mathrm{ns}}$ \\
\hline & $0.2-0.4$ & 200 & 201 & 12.41 & -0.05 & -0.84 & $0.08^{n s}$ \\
\hline \multirow{2}{*}{ Sand $\left(\mathrm{g} \mathrm{kg}^{-1}\right)$} & $0.0-0.2$ & 168 & 169 & 7.37 & -0.26 & 1.45 & 0.14 \\
\hline & $0.2-0.4$ & 163 & 162 & 8.38 & -0.33 & -0.04 & $0.07 \mathrm{~ns}$ \\
\hline
\end{tabular}

${ }^{(1)}$ GMD: geometric mean diameter. ${ }^{(2)}$ MWD: mean weight diameter. ${ }^{(3)}>2 \mathrm{~mm}$ : aggregates in class $>2$ mm. ${ }^{(4)} \mathrm{OM}$ : organic matter proportion. ${ }^{(5)} \mathrm{d}$ : ${ }^{\text {ns }}$ not significant at $5 \%$ by the Kolmogorov-Smirnov test.

particular attribute, therefore the logarithmic transformation is not required for data normalization. Values between 0.5 and 1.0 require chi-square analysis for a bias-check of a log-normal distribution and asymmetry values of over 1.0 require logarithmic transformation to ensure a regular distribution.

Based on the coefficient of variation classification of Warrick \& Nielsen (1980), the mean CV of the variable organic matter was $12 \%<\mathrm{CV}<24 \%$ in $\mathrm{ERL}$ and DRL in the studied layers (Table 1). The CV of the variables GMD and MWD and aggregates in the $>2.0 \mathrm{~mm}$ class in ERL and DRL was high (CV > $24 \%)$ in both studied layers. According to Vanni (1998), a $\mathrm{CV}$ of over $35 \%$ shows that the data set is heterogeneous and the mean is little relevant. If it is over $65 \%$, the data set is highly heterogeneous and the mean insignificant. However, if it is less than $35 \%$, the data set is homogeneous, the mean significant and it can be used as representative of the original data set. The data of GMD and aggregates in the $>2.0 \mathrm{~mm}$ class in the layers $0.0-0.2$ and $0.2-0.4 \mathrm{~m}$ were heterogeneous ( $\mathrm{CV}>35 \%)$ and the mean was little significant.

All analyzed variables were spatially dependent in both soil and layer classes studied (Table 2 and Figures 2 and 3). The analysis of the semi-variograms for the properties under study did not indicate any preferential direction, in other words, the data spatial variability occurred equally in all directions and no anisotropy of the data was stated (Vieira, 2000).

The spherical model was adjusted to the data of all studied variables, except the MWD in the 0.0-0.2 m layer in the ERL, which fit the exponential model. The spherical and exponential mathematical models were most compatible with the ideal indicators by the "Jack-Knifing" self validation procedure, using GS ${ }^{+}$ user's guide version 5. Plainwell, Gamma Design. These are considered transition models (Isaaks \& Srivastava, 1989), for they have a sill, in other words, 
Table 2. Estimated models and parameters for experimental semi-variograms for the variables geometric mean diameter, mean weight diameter, aggregates in class $>2.0 \mathrm{~mm}$ and organic matter proportion, in an eutrophic Red Latosol and a dystrophic Red Latosol in the soil layers 0.0-0.2 and 0.2-0.4 m

\begin{tabular}{|c|c|c|c|c|c|c|c|}
\hline \multirow{2}{*}{ Attributes } & \multirow{2}{*}{ Layer } & \multicolumn{6}{|c|}{ Semi -variogram Parameters } \\
\hline & & $\mathrm{C}_{0}^{(5)}$ & Sill & Range & Model & $\mathrm{r}^{2^{(6)}}$ & $\mathrm{C}_{0} /\left(\mathrm{C}_{0}+\mathrm{C}_{1}\right)^{(7)}$ \\
\hline \multicolumn{8}{|c|}{$\mathrm{m}$} \\
\hline \multicolumn{8}{|c|}{ dystrophic Red Latosol } \\
\hline \multirow{2}{*}{ GMD $(\mathrm{mm})^{(1)}$} & $0.0-0.2$ & 0.07 & 0.30 & 18 & Spherical & 84 & 23 \\
\hline & $0.2-0.4$ & 0.05 & 0.20 & 16 & Spherical & 83 & 25 \\
\hline \multirow{2}{*}{$\mathrm{WMD}(\mathrm{mm})^{(2)}$} & $0.0-0.2$ & 0.001 & 0.79 & 19 & Spherical & 81 & 1 \\
\hline & $0.2-0.4$ & 0.12 & 0.66 & 16 & Spherical & 86 & 18 \\
\hline \multirow{2}{*}{$>2.0 \mathrm{~mm}(\%)^{(3)}$} & $0.0-0.2$ & 0.11 & 230.41 & 19 & Spherical & 90 & 1 \\
\hline & $0.2-0.4$ & 18.40 & 136.10 & 17 & Spherical & 90 & 14 \\
\hline \multirow{2}{*}{$\mathrm{OM}\left(\mathrm{g} \mathrm{dm}^{-3}\right)^{(4)}$} & $0.0-0.2$ & 0.08 & 2.85 & 21 & Spheri cal & 93 & 3 \\
\hline & $0.2-0.4$ & 0.27 & 3.44 & 22 & Spherical & 95 & 8 \\
\hline \multicolumn{8}{|c|}{ eutrophic Red Latosol } \\
\hline \multirow{2}{*}{ GMD (mm) } & $0.0-0.2$ & 0.05 & 0.20 & 34 & Spherical & 98 & 25 \\
\hline & $0.2-0.4$ & 0.04 & 0.19 & 31 & Spherical & 95 & 21 \\
\hline \multirow{2}{*}{ WMD (mm) } & $0.0-0.2$ & 0.11 & 0.46 & 58 & Exponential & 94 & 24 \\
\hline & $0.2-0.4$ & 0.22 & 0.53 & 70 & Spherical & 95 & 41 \\
\hline \multirow{2}{*}{$>2.0 \mathrm{~mm}(\%)$} & $0.0-0.2$ & 24.31 & 48.70 & 70 & Spherical & 90 & 50 \\
\hline & $0.2-0.4$ & 0.71 & 10.01 & 21 & Spherical & 94 & 7 \\
\hline \multirow{2}{*}{$\mathrm{OM}\left(\mathrm{g} \mathrm{dm}^{-3}\right)$} & $0.0-0.2$ & 1.45 & 3.00 & 77 & Spherical & 99 & 48 \\
\hline & $0.2-0.4$ & 0.21 & 5.94 & 60 & Spherical & 98 & 4 \\
\hline
\end{tabular}

${ }^{(1)}$ GMD: geometric mean diameter. ${ }^{(2)}$ MWD: mean weight diameter. ${ }^{(3)}>2 \mathrm{~mm}$ : aggregates in class $>2 \mathrm{~mm} .{ }^{(4)}$ OM: organic matter proportion. ${ }^{(5)} \mathrm{C}_{0}$ : nugget effect. ${ }^{(6)} \mathrm{r}^{2}$ : determination coefficient. ${ }^{(7)} \mathrm{C}_{0} /\left(\mathrm{C}_{0}+\mathrm{C}_{1}\right)$ : spatial dependence grade.

from a determined distance value between the samples, there is no more spatial dependence (the variance of the difference between sample pairs becomes stable with the distance) The spherical and exponential models appear as the most common theoretical models of soil and plant properties (Trangmar et al., 1985; Cambardella et al., 1994; Vieira, 2000).

The $\mathrm{C}_{0} /\left(\mathrm{C}_{0}+\mathrm{C}_{1}\right)$ ratio showed strong spatial dependence level of all soil properties in the soil and layer classes studied, except of the MWD in the $0.2-$ $0.4 \mathrm{~m}$ layer and aggregates in the $>2.0 \mathrm{~mm}$ class and the organic matter content in the 0.0-0.2 m layer in ERL. The OM content was highest for the range in the 0.0-0.2 $\mathrm{m}$ layer in ERL. The values for the range were lowest for the properties of GMD and MWD in the $0.2-0.4 \mathrm{~m}$ layer in DRL.

A number of properties of the eutrophic Red Latosol (ERL) had lower CV values and greater range when compared to the dystrophic Red Latosol (DRL), indicating greater variability and lower homogenization of aggregates of the DRL, compared to the ERL. This agrees with the soil-landscape relationship models, when different Latosol classes occupy geomorphic surfaces and similar side locations. Since the DRL is originated from geologically younger sandstone, it has a lower evolution level, expressed in a more kaolinitic mineralogy, compared with the pedogenetically more evolved ERL originated from the basalt.
The GMD represents a size class estimate of the most frequent aggregates. It was observed that the GMD values of 90 and $94 \%$ in the DRL and 15 and $14 \%$ in the ERL, in the layers 0.0-0.2 and 0.2-0.4 $\mathrm{m}$, respectively, are under $2.0 \mathrm{~mm}$ (Table 3, Figures 2 and 3 ). The MWD increases according to the percentage of large aggregates retained in strainers with larger screens. The MWD values in approximately 81 and $86 \%$ of the area in the DRL and 4 and $8 \%$ in the ERL, in the layers $0.0-0.2$ and $0.2-0.4 \mathrm{~m}$, respectively, were under $3.0 \mathrm{~mm}$. For the aggregate class $>2.0 \mathrm{~mm}$ in the layers $0.0-0.2$ and $0.2-0.4 \mathrm{~m}, 84$ and $94 \%$ of the values in the DRL area and 0 and $1 \%$ in the ERL, respectively, were below the $47-60.0 \mathrm{~mm}$ class

The OM contents varied from low to medium in the studied soils; a value is considered high when it is over $25 \mathrm{~g} \mathrm{dm}^{-3}$. An analysis of the chart of the OM content and area percentage of each class (Table 3 and Figures 2 and 3), shows that values were high in $100 \%$ of the area in the ERL for the 0.0-0.2 m layer, while in the $0.2-0.4 \mathrm{~m}$ layer values were under $25 \mathrm{~g} \mathrm{dm}^{-3}$ in $77 \%$ of the area. In the DRL values were under $25 \mathrm{~g} \mathrm{dm}^{-3}$ in $100 \%$ of the area, in the $0.0-0.2$ and $0.2-0.4 \mathrm{~m}$ layers. The greater $\mathrm{OM}$ content in the ERL probably contributed to a greater aggregate stability in the DRL.

The mean values and area percentages of each class showed that the values of the properties GMD, MWD, 

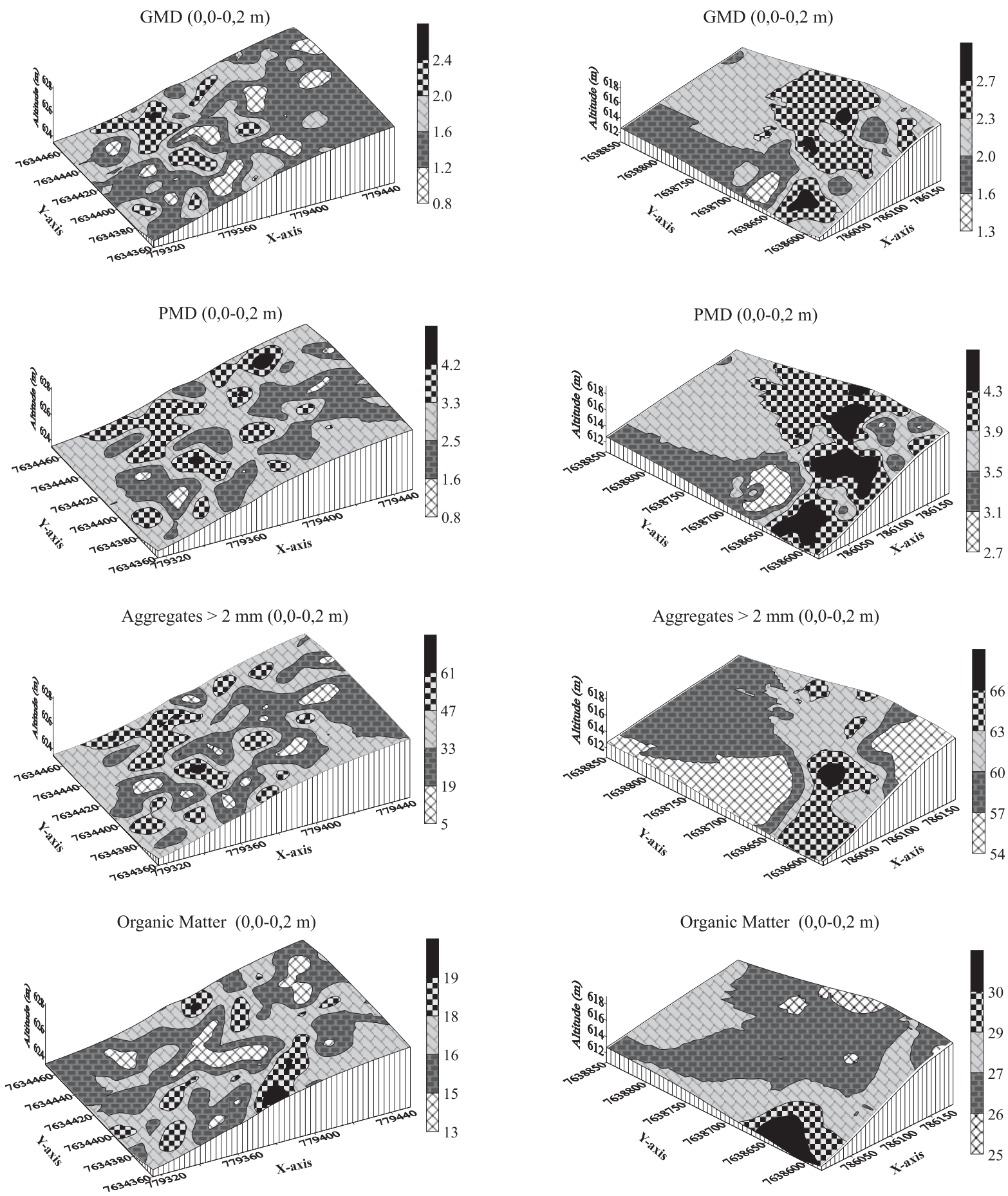

DYSTROPHIC RED LATOSOL

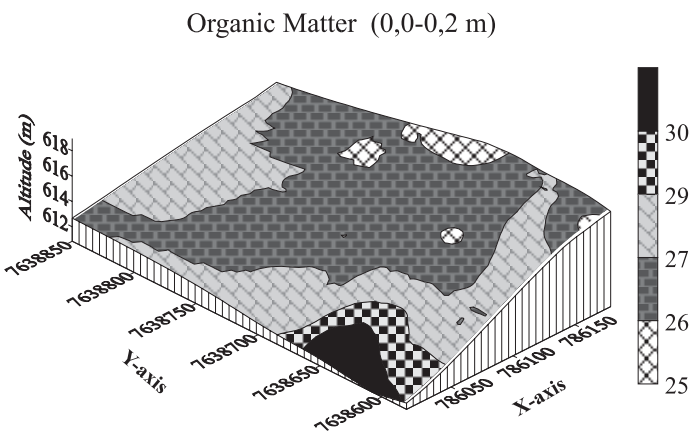

EUTROPHIC RED LATOSOL

Figure 2. Spatial distribution of the variables geometric mean diameter ( $\mathrm{mm})$, mean weight diameter (mm), aggregates in class $>2.0 \mathrm{~mm}(\%)$ and organic matter proportion $\left(\mathrm{g} \mathrm{dm}^{-3}\right)$, in an eutrophic Red Latosol (ERL) and a dystrophic Red Latosol (DRL) in 0.0-0.2 m layer.

of the aggregate size class $>2.0 \mathrm{~mm}$, and organic matter and clay contents were higher in the ERL than in the DRL, in both layers under study (Tables 1 and 3 , Figures 2 and 3). This was associated, partially, to the higher values of organic substance in ERL, mainly in the layer $0.0-0.2 \mathrm{~m}$, which allows the presence of more stable aggregates in the surface layers. The effects of organic substance on aggregation are reported in literature by several authors (Silva \& Mielniczuk, 1997; Sá et al., 2000; Corrêa, 2002). The clay content is higher in ERL, contributing to a higher aggregation in this soil class compared to DRL. Dufranc et al. 
$\operatorname{GMD}(0,2-0,4 \mathrm{~m})$

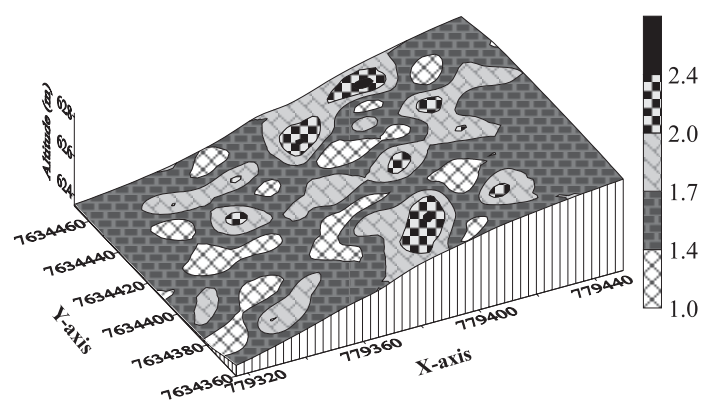

$\operatorname{PMD}(0,2-0,4 \mathrm{~m})$

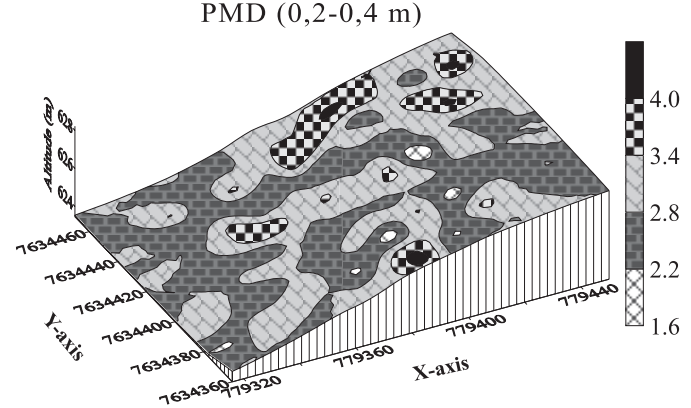

Aggregates $>2 \mathrm{~mm}(0,2-0,4 \mathrm{~m})$

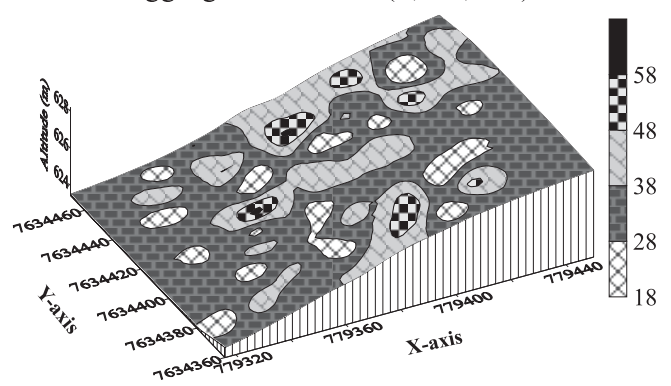

Organic Matter $(0,2-0,4 \mathrm{~m})$

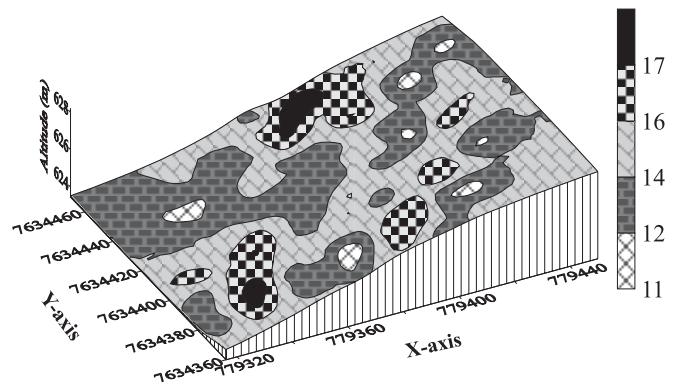

DYSTROPHIC RED LATOSOL
$\operatorname{GMD}(0,2-0,4 \mathrm{~m})$
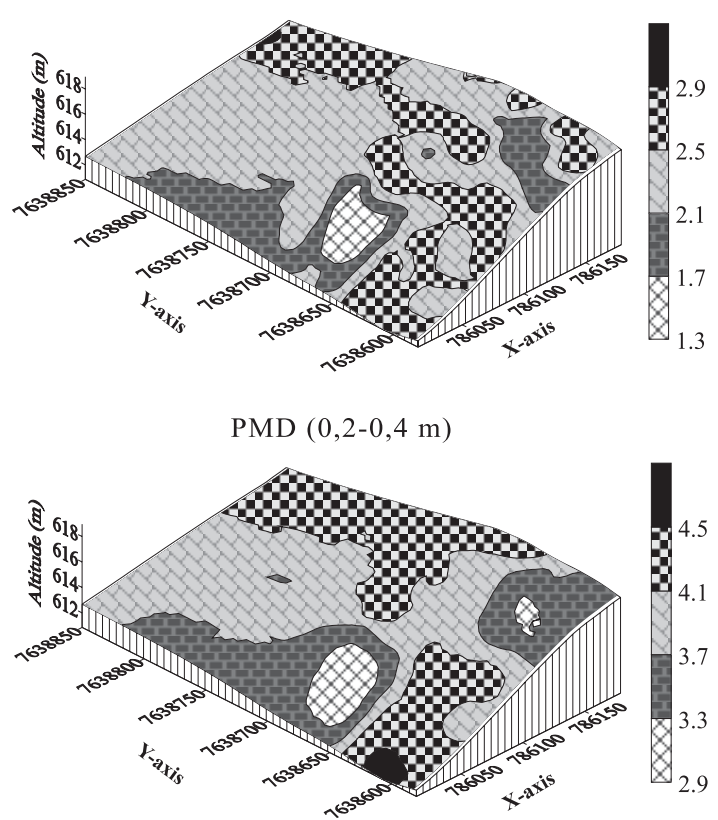

Aggregates $>2 \mathrm{~mm}(0,2-0,4 \mathrm{~m})$

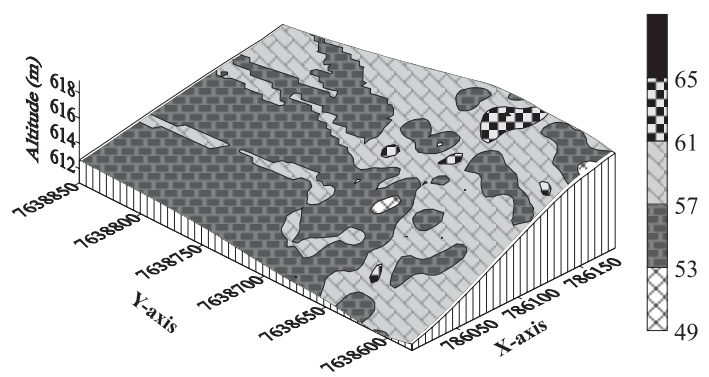

Organic Matter $(0,2-0,4 \mathrm{~m})$

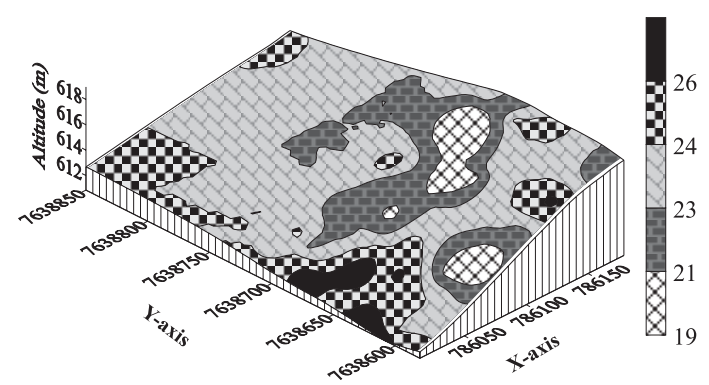

EUTROPHIC RED LATOSOL

Figure 3. Spatial distribution of the variables geometric mean diameter ( $\mathrm{mm})$, mean weight diameter (mm), aggregates in class $>2.0 \mathrm{~mm}(\%)$ and organic matter proportion $\left(\mathrm{g} \mathrm{dm}^{-3}\right)$, in an eutrophic Red Latosol (ERL) and a dystrophic Red Latosol (DRL) in 0.2-0.4 m layer.

(2004) studied the physical, chemical and biological properties related to the aggregate stability of two Latosols in the State of São Paulo and claimed that in soils with a high clay content a high aggregate stability is to be expected.
This behavior is also related to higher gibbsite contents in ERL and higher kaolinite contents in DRL, in agreement with the results obtained by Lima et al. (1990) and Ferreira et al. (1999) that confirm that aggregate stability in water is lower in the kaolinitic 
Table 3. Area percentage of each class for the properties geometric mean diameter (mm), mean weight diameter $(\mathrm{mm})$, aggregates in class $>2.0 \mathrm{~mm}(\%)$ and organic matter proportion $\left(\mathrm{g} \mathrm{dm}^{-3}\right)$, in an eutrophic Red Latosol and a dystrophic Red Latosol in layers of 0.0-0.2 and 0.2-0.4 m

\begin{tabular}{|c|c|c|c|c|c|c|c|}
\hline \multicolumn{8}{|c|}{ Class Percentage (\%) } \\
\hline Class & GMD $^{(1)}$ & Class & $\mathrm{WMD}^{(2)}$ & Class & $>2.0 \mathrm{~mm}^{(3)}$ & Class & $\mathrm{OM}^{(4)}$ \\
\hline \multicolumn{8}{|c|}{ dystrophic Red Latosol (0.0-0.2 m) } \\
\hline $0.8-1.2$ & 13 & $0.8-1.6$ & 6 & $5-19$ & 5 & $13-15$ & 16 \\
\hline $1.2-1.6$ & 52 & $1.6-2.5$ & 21 & $19-33$ & 57 & $15-16$ & 30 \\
\hline $1.6-2.0$ & 25 & $2.5-3.3$ & 54 & $33-47$ & 22 & $16-18$ & 41 \\
\hline $2.0-2.4$ & 9 & $3.3-4.2$ & 16 & $47-61$ & 14 & $18-19$ & 9 \\
\hline$>2.4$ & 1 & $>4.2$ & 3 & $>61$ & 2 & $>19$ & 4 \\
\hline \multicolumn{8}{|c|}{ dystrophic Red Latosol (0.2-0.4 m) } \\
\hline $1.0-1.4$ & 9 & $1.6-2.2$ & 2 & $18-28$ & 9 & $11-12$ & 8 \\
\hline $1.4-1.7$ & 68 & $2.2-2.8$ & 47 & $28-38$ & 70 & $12-14$ & 34 \\
\hline $1.7-2.0$ & 17 & $2.8-3.4$ & 39 & $38-48$ & 15 & $14-16$ & 45 \\
\hline $2.0-2.4$ & 5 & $3.4-4.0$ & 10 & $48-58$ & 5 & $16-17$ & 10 \\
\hline$>2.4$ & 1 & $>4.0$ & 2 & $>58$ & 1 & $>17$ & 3 \\
\hline \multicolumn{8}{|c|}{ eutrophic Red Latosol $\quad(0.0-0.2 \mathrm{~m})$} \\
\hline $1.3-1.6$ & 2 & $2.7-3.1$ & 4 & $54-57$ & 18 & $25-26$ & 6 \\
\hline $1.6-2.0$ & 13 & $3.1-3.5$ & 10 & $57-60$ & 36 & $26-27$ & 44 \\
\hline $2.0-2.3$ & 66 & $3.5-3.9$ & 56 & $60-63$ & 32 & $27-29$ & 37 \\
\hline $2.3-2.7$ & 15 & $3.9-43$ & 17 & $63-66$ & 11 & $29-30$ & 7 \\
\hline$>2.7$ & 4 & $>4.3$ & 13 & $>66$ & 3 & $>30$ & 6 \\
\hline \multicolumn{8}{|c|}{ eutrophic Red Latosol (0.2-0.4 m) } \\
\hline $1.3-1.7$ & 5 & $2.9-3.3$ & 8 & $49-53$ & 1 & $19-21$ & 12 \\
\hline $1.7-2.1$ & 9 & $3.3-3.7$ & 16 & $53-57$ & 38 & $21-23$ & 19 \\
\hline $2.1-2.5$ & 70 & $3.7-4.1$ & 46 & $57-61$ & 56 & $23-24$ & 46 \\
\hline $2.5-2.9$ & 15 & $4.1-4.5$ & 28 & $61-65$ & 4 & $24-26$ & 17 \\
\hline$>2.9$ & 1 & $>4.5$ & 2 & $>65$ & 1 & $>26$ & 6 \\
\hline
\end{tabular}

${ }^{(1)}$ GMD: geometric mean diameter. ${ }^{(2)}$ MWD: mean weight diameter. ${ }^{(3)}>2 \mathrm{~mm}$ : aggregates in class $>2$ mm. ${ }^{(4)}$ OM: organic matter proportion.

Latosols than in gibbsite Latosols. Carpenedo \& Mielniczuk (1990) reported that different management systems reduced the percentage of aggregates of over $2.0 \mathrm{~mm}$ from 58 to $38 \%$ in dystrophic Red Latosol and from 35 to $17 \%$ in eutrophic Red Latosol. According to Souza et al. (2005) if sugar cane areas are not burned and mechanical harvest eliminated (raw sugar cane) the OM content increases and aggregate stability is improved. Therefore, the maintenance of crop residues in the area is fundamental for sugar cane management, to avoid modifications of the soil structure and consequent soil degradation.

\section{CONCLUSIONS}

1. The aggregate stability of the eutrophic Red Latosol (ERL) was higher than of the dystrophic Red Latosol (DRL) and may be attributed to the higher clay and organic matter content and the gibbsitic mineralogy of this soil class.

2. The differentiated evolution of studied Oxisols explains the greater range, lower variation coefficient and lower variability observed in the eutrophic Red Latosol (ERL) for all properties studied.

\section{LITERATURE CITED}

CAMBARDELLA, C.A.; MOORMAN, T.B.; NOVAK, J.M.; PARKIN, T.B.; KARLEN, D.L.; TURCO, R.F. \& KONOPKA, A.E. Field-scale variability of soil properties in Central Iowa Soils. Soil Sci. Soc. Am. J., 58:1501-1511, 1994.

CARPENEDO, V. \& MIELNICZUK, J. Estado de agregação e qualidade de agregados de Latossolos Roxos, submetidos a diferentes sistemas de manejo. R. Bras. Ci. Solo, 14:99$105,1990$.

CORREAA, J.C. Efeito de sistemas de cultivo na estabilidade de agregados de um Latossolo Vermelho-Amarelo em Querência, MT. Pesq. Agropec. Bras., 37:203-209, 2002.

DUFRANC, G.; DECHEN, S.C.F.; FREITAS, S.S. \& CAMARGO, O.A. Atributos físicos, químicos e biológicos relacionados com a estabilidade de agregados de dois Latossolos em plantio direto no estado de São Paulo. R. Bras. Ci. Solo, 28:505-517, 2004.

EASTMAN, J.R. Guide to GIS and image processing. IDRISI 32. Worcester, Clark University, 1999. 193p. v.1. 
EMPRESA BRASILEIRA DE PESQUISA AGROPECUÁRIA EMBRAPA. Centro Nacional de Pesquisa de Solos (Rio de Janeiro, RJ). Sistema brasileiro de classificação de solos. Brasília, 1999. 412p.

EMPRESA BRASILEIRA DE PESQUISA AGROPECUÁRIA EMBRAPA. Manual de métodos de análise de solo. 2.ed. Rio de Janeiro, Ministério da Agricultura e do Abastecimento, 1997. 212p.

FERREIRA, M.M.; FERNANDES, B. \& CURI, N. Influência da mineralogia da fração argila nas propriedades físicas de Latossolos da região sudeste do Brasil. R. Bras. Ci. Solo, 23:515-524, 1999.

GOLDEN SOFTWARE INC. (Golden, Estados Unidos). Surfer for Windows: Release 7.0, contouring and 3D surface mapping for scientist's engineers User's Guide. New York, 1999. 619p.

ISAAKS, E.H. \& SRIVASTAVA, R.M. An introduction to applied geostatistics. New York, Oxford University, 1989. 561p.

KEMPER, W.D. \& CHEPIL, W.S. Size distribution of aggregates. In: BLACK, C.A., ed. Methods of soil analysis. Madison, American Society Agronomy, 1965. p.499-510.

LIMA, J.M.; CURI, N.; RESENDE, M. \& SANTANA, D.P. Dispersão do material de solo em água para avaliação indireta da erodibilidade de Latossolos. R. Bras. Ci. Solo, 14:85-90, 1990.

LITTLE, T.M. \& HILLS, F.J. Agricultural experimentation. New York, John Wiley \& Sons, 1978. 350p.

ROBERTSON, G.P. GS ${ }^{+}$: Geostatistics for the environmental sciences - GS ${ }^{+}$User's Guide. Plainwell, Gamma Design Software , 1998. 152p.
SÁ, M.A.C.; LIMA, J.M.; SILVA, M.L.N. \& DIAS JUNIOR, M.S. Comparação entre métodos para estudo da estabilidade de agregados em Solo. Pesq. Agropec. Bras., 35:2043-2053, 2000 .

SCHLOTZHAVER, S.D. \& LITTELL, R.C. SAS: System for elementary statistical analysis. 2.ed. Cary, SAS, 1997.

SILVA, I.F. \& MIELNICZUK, J. Ação do sistema radicular de plantas na formação e estabilização de agregados do solo. R. Bras. Ci. Solo, 21:111-117, 1997.

SOUZA, Z.M.; PRADO, R.M.; PAIXÃO, A.C.S.P. \& CESARIN, L.G. Sistemas de colheita e manejo da palhada de canade-açúcar. Pesq. Agropec. Bras., 40:271-278, 2005.

TRANGMAR, B.B.; YOST, R.S.; WADE, M.K. \& UEHARA, G. Applications of geostatistics to spatial studies of soil properties. Adv. Agron., 38:45-94, 1985.

VANNI, S.M. Modelos de regressão: Estatística aplicada. São Paulo, Legmar Informática, 1998. 177p.

VIEIRA, S.R. Geoestatística em estudos de variabilidade espacial do solo. In: NOVAIS, R.F.; ALVAREZ V., V.H. \& SCHAEFER, C.E.G.R., eds. Tópicos em ciência do solo. Viçosa, MG, Sociedade Brasileira de Ciência do Solo, 2000. v.1. p.1-53.

WARRICK, A.W. \& NIELSEN, D.R. Spatial variability of soil physical properties in the field. In: HILLEL, D., ed. Applications of soil physics. New York, Academic Press, 1980. p.319-344.

WEBSTER, R. Statistics to support soil research and their presentation. Eur. J. Soil Sci., 52:331-340, 2001. 
